\title{
Knowledge, Attitude and Practice of Mothers Towards Newborn Care in Jugal Hospital, Harari Regional State, Ethiopia
}

\section{Arif Hussen Jamie ${ }^{1}$ and Rafika Amin ${ }^{2}$}

${ }^{1}$ Department of Paediatrics Nursing, Harar Health Science College, East Ethiopia

${ }^{2}$ Operation Room, Harar Jugal hospital, East Ethiopia

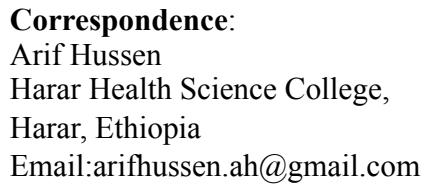

DOI: $10.3126 /$ jnps.v41i2.34397

Submitted on: 2021-01-20

Accepted on: 2021-06-27

Acknowledgements: None

Funding: Nil

Conflict of Interest: None declared

Permission from IRB: Yes

To cite this article: Jamie AH, Amin R. Knowledge, Attitude and Practice of Mothers Towards Newborn Care in Jugal Hospital, Harari Regional State, Ethiopia. J Nepal Paediatr Soc. 2021;41(2):190-6.

\section{ABSTRACT}

Introduction: Globally every year about four million neonates die in the first 28 days of life and similar number of babies is stillborn. Most neonatal deaths $(99 \%)$ occur in low income and middle-income countries. The global neonatal mortality rate is 18 , in Africa it is 26.7 and in Ethiopia, it is 30 per 1000 live births in 2019. In Ethiopia, neonatal mortality remains high and accounts for about half of the under-five mortality. There are relatively fewer studies regarding knowledge, attitude and practice of mothers towards newborn care in Ethiopia. However, no such study has been done in Harari region. So, this study was planned to assess the knowledge, attitude and practice of newborn care among postnatal mothers in Harari regional state, Ethiopia.

Methods: An institutional based cross-sectional study was conducted among postnatal mothers who were randomly selected from Jugal hospital. A systematic random sampling method was followed. A pretested questionnaire was used. Data was entered, cleaned and analysed using SPSS version 20.

Results: A total of 414 postnatal mothers were interviewed with a response rate of $98.1 \%$, among them $74 \%$ had good knowledge, $77.14 \%$ had positive attitude and $65.45 \%$ had good practice of newborn care.

Conclusions: This study indicated that nearly half and above respondents had good knowledge, positive attitude and good practice of newborn care, but a substantial number of postpartum mothers had poor knowledge and practice on newborn care in Harari Region. Therefore, provision of information, education and communication and regular training and workshops about newborn care should be done to health professional working at $\mathrm{MCH}$ unit in order to increase the awareness of mothers through health education.

Key words: Attitude; Knowledge; Newborn Care; Postnatal mothers; Practice

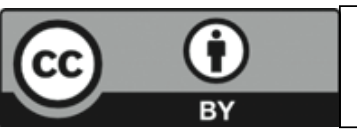

This work is licensed under creative common attribution 3.0 license 


\section{INTRODUCTION}

Globally every year about four million neonates die in the first four weeks of life. A similar number of babies are stillborn. Most neonatal deaths (99\%) occur in low income and middle-income countries. ${ }^{1}$ Each year in Africa, 30 million women become pregnant and around 18 million give birth at home without skilled care. Each day, 3,100 newborns die and another 2,400 are stillborn. Also 9,600 children die after their first month of life and before their fifth birthday each day. ${ }^{2}$

In Ethiopia, 2016 Ethiopian Demographic and Health Survey results showed that neonatal, infant and under- 5 mortality rates for the 5 years were 29 , 48 and 67 deaths per 1,000 live births, respectively. In other words, in Ethiopia one in every 35 children dies within the first month, one in every 21 children dies before celebrating the first birthday, and one in every 15 children dies before reaching the fifth birthday. In Ethiopia, suboptimal newborn care practices still persist and neonatal mortality rates have been resistant to change and contributes about $43 \%$ of all under - five deaths. ${ }^{3}$

Study in four different regions (Amhara, Oromia, Tigray and Southern Nations, and Nationalities and People Region) of Ethiopia revealed that mothers' unprompted knowledge of newborn danger signs was rather low with only $29.3 \%$ of respondents being able to name three or more danger signs out of a list of $11 .{ }^{4}$ Study done in Eastern Tigray showed essential newborn care knowledge and practice of mothers revealed that $80.4 \%$ had good knowledge and $92.9 \%$ had good practice. Most mothers had good knowledge on temperature maintenance, breast feeding initiation and first bathing time. ${ }^{5}$ Insufficient knowledge of parents during this period could lead to parents' confusion and decreased quality of care that in turn threaten the neonatal health and could even contribute to significant neonatal morbidity and mortality as well. ${ }^{6}$

There is a significant dearth of research on this field from our region. In view of this, this study was designed to assess knowledge, attitude and practice of mothers towards newborn care in Harari region of Ethiopia. This study has been aimed to contribute in reducing the neonatal morbidity and mortality in the future in Africa and other developing regions of the world.

\section{METHODS}

The study was conducted at Jugal hospital, Harar city, Ethiopia. Harar city is located around $500 \mathrm{~km}$ east of Addis Ababa, the capital city of Ethiopia. Our hospital is the first Governmental hospital in Ethiopia established in 1902, named as Misrak Arbegnoch Hospital and the hospital changed its name to Jugal hospital. Currently, the hospital has around 208 health care professionals and nonhealth professionals for administrative facilitation. We have four adult OPDs, one Paediatrics OPD, Emergency Department and one follow up clinic. On average, at daily basis from Monday to Friday, a total of around 150-180 patients are seen. Regarding the number of deliveries, on average, around 31 deliveries occur per day. Among those, around four to five deliveries are conducted by emergency and elective Caesarean sections each. We conceptualised institutional based quantitative cross sectional study to assess knowledge, attitude and practice of mothers towards newborn care. The Ethical approval was granted by Harar Health Science College Research ethical committee (No. HHSC-06130/2019). Data were collected from July $1^{\text {st }}$ to $15^{\text {th }}$ July, 2019. A total of 418 samples were calculated using a single population proportion formula by assuming 5\% marginal error and $95 \%$ confidence interval $(\sigma=0.05)$ and by estimation of the proportion of mothers' knowledge and practice considering to be $44.7 \%,{ }^{4}$ and by adding $10 \%$ of non-response rate. Mothers who consented to study were included and mothers who were sick, nonresponsive or who had lost their baby were excluded. A systematic random sampling methods was used by skipping 2 mothers until sample size fulfilled. Data were collected by interview method using structured questionnaire. The questionnaire were gathered and checked for completeness. Data were coded and entered into SPSS version 20. Data analysis was done using descriptive as well as inferential statistics. Univariate, bi-variate and multivariate analysis was carried out. Odds ratio (OR) with confidence intervals and $\mathrm{p}$-values were calculated. P - value of $\leq 0.05$ taken as level of significance. Participants who scored greater than or equal to the mean were considered knowledgeable and the others were labeled as not knowledgeable. Respondents who scored greater 
than or equal the proxy variable were considered as having positive attitude and those who scored less than the proxy variable were considered as having negative attitude. Respondents who scored greater than or equal to the proxy variable were considered as having good practice and those who scored less than the proxy variable were considered as not having good practice.

\section{RESULTS}

Table 1 shows that among 418 postnatal mothers enrolled, 414 respondents were interviewed making response rate $99 \%$. Mean age of the respondents was $26.8(\mathrm{SD} \pm 3.78)$ years with a minimum and maximum age of 18 years and 39 years respectively. Most of the study participants 199 $(48.07 \%)$ were in the age group of 25 to 29 years. Majority of respondents $361(87.2 \%)$ were married and 163 (39.37\%) were house wife.

Table 2 reveals that among all the respondents who had attended antenatal clinic, 216 (52.17\%) were multi-parous, one fourth $\{102(24.64 \%)\}$ were delivered through Caesarean section and majority of mothers gave birth to female babies.

We found that among the respondents, 382 $(92.27 \%)$ had received different information

Table 2. Antenatal, Natal and Postnatal Information of the Respondents $(\mathrm{N}=414)$

\begin{tabular}{|c|c|c|c|}
\hline Variables & & Frequency & $\%$ \\
\hline \multirow[t]{2}{*}{ Parity } & Primi & 198 & 47.83 \\
\hline & Multi & 216 & 52.17 \\
\hline \multirow{4}{*}{$\begin{array}{l}\text { Pregnancy in } \\
\text { month at first } \\
\text { visit }\end{array}$} & $1-2$ & 77 & 18.60 \\
\hline & $3-4$ & 193 & 46.62 \\
\hline & $5-6$ & 56 & 13.53 \\
\hline & 7 and above & 88 & 21.26 \\
\hline \multirow{3}{*}{$\begin{array}{l}\text { No of Antenatal } \\
\text { visit }\end{array}$} & $2-3$ & 313 & 75.60 \\
\hline & $4-5$ & 70 & 16.91 \\
\hline & 6 and above & 31 & 7.49 \\
\hline \multirow[t]{2}{*}{ Mode of delivery } & $\begin{array}{l}\text { Vaginal } \\
\text { delivery }\end{array}$ & 312 & 75.36 \\
\hline & $\begin{array}{l}\text { Caesarean } \\
\text { section }\end{array}$ & 102 & 24.64 \\
\hline \multirow{2}{*}{$\begin{array}{l}\text { Delivery room } \\
\text { stay after } \\
\text { delivery }\end{array}$} & 2 - 3 Hours & 312 & 75.36 \\
\hline & 2 - 5 Days & 102 & 24.64 \\
\hline \multirow{2}{*}{$\begin{array}{l}\text { Sex of the } \\
\text { neonate }\end{array}$} & Male & 113 & 27.29 \\
\hline & Female & 301 & 72.71 \\
\hline
\end{tabular}

Table 1. Distribution of Socio demographic Characteristics of Respondents $(\mathrm{N}=414)$

\begin{tabular}{|c|c|c|c|}
\hline Variable & & Frequency & $\%$ \\
\hline \multirow{5}{*}{$\begin{array}{l}\text { Age of } \\
\text { mother in } \\
\text { years }\end{array}$} & $15-19$ & 32 & 7.73 \\
\hline & $20-24$ & 91 & 21.98 \\
\hline & $25-29$ & 199 & 48.07 \\
\hline & $30-34$ & 67 & 16.18 \\
\hline & $35-39$ & 25 & 6.04 \\
\hline \multirow{3}{*}{$\begin{array}{l}\text { Marital } \\
\text { status }\end{array}$} & Single & 29 & 7.00 \\
\hline & Married & 361 & 87.20 \\
\hline & Divorced & 24 & 5.80 \\
\hline \multirow[t]{5}{*}{$\begin{array}{l}\text { Educational } \\
\text { status }\end{array}$} & $\begin{array}{l}\text { No formal } \\
\text { education }\end{array}$ & 29 & 7.00 \\
\hline & $\begin{array}{l}\text { Able to read and } \\
\text { write }\end{array}$ & 89 & 21.50 \\
\hline & Primary & 133 & 32.13 \\
\hline & Secondary & 93 & 22.46 \\
\hline & $\begin{array}{l}\text { Diploma and } \\
\text { above }\end{array}$ & 70 & 16.91 \\
\hline \multirow{3}{*}{ Employment } & Housewife & 163 & 39.37 \\
\hline & Private & 119 & 28.74 \\
\hline & Government & 132 & 31.8 \\
\hline
\end{tabular}

regarding newborn care and the remaining 32 (7.73\%) had not received any information regarding newborn care. Of those who had received information / education regarding newborn care, $61.35 \%$ mentioned that nurses provided the information. Regarding the type of information, received, $99.28 \%$ of respondents had received information regarding immunisation and 399 (96.38\%) received information regarding breastfeeding.

Table 3. Source and type of information received, by Respondents $(\mathrm{N}=382)$

\begin{tabular}{|llrc|} 
Variable & & Frequency & \multicolumn{1}{c}{$\%$} \\
\hline $\begin{array}{l}\text { Provider of } \\
\text { information } \\
\text { on newborn } \\
\text { care }\end{array}$ & Doctor & 118 & 28.50 \\
& Family & 254 & 61.35 \\
& Media (e.g. & 184 & 44.44 \\
& pamphlets, & 211 & 50.97 \\
& brochures, & & \\
& magazines) & & \\
& Peers / friends & 111 & 26.81 \\
Type of & Breastfeeding & 399 & 96.38 \\
information \\
received & Cord care & 313 & 75.60 \\
& Eye care & 85 & 20.53 \\
& Thermoregulation & 10 & 2.42 \\
& Immunization & 411 & 99.28
\end{tabular}


Table 4. Respondents knowledge on breast feeding and thermoregulation of newborn $(\mathrm{N}=414)$

\begin{tabular}{|c|c|c|c|c|}
\hline \multicolumn{2}{|l|}{ Variable } & \multicolumn{2}{|r|}{ frequency } & $\%$ \\
\hline \multirow{8}{*}{$\begin{array}{l}\text { Breast } \\
\text { feeding }\end{array}$} & \multirow{2}{*}{$\begin{array}{l}\text { Immediate breast } \\
\text { feeding soon after } \\
\text { delivery }\end{array}$} & Yes & 381 & 92.03 \\
\hline & & No & 33 & 7.97 \\
\hline & \multirow{2}{*}{$\begin{array}{l}\text { Exclusive } \\
\text { breastfeeding for } \\
\text { six months }\end{array}$} & Yes & 323 & 78.02 \\
\hline & & No & 91 & 21.98 \\
\hline & \multirow{2}{*}{$\begin{array}{l}\text { Babies should be } \\
\text { breastfed on } \\
\text { demand }\end{array}$} & Yes & 277 & 66.91 \\
\hline & & No & 137 & $33.0 \mathrm{~s}$ \\
\hline & \multirow{2}{*}{$\begin{array}{l}\text { Colostrums' } \\
\text { should be given to } \\
\text { baby }\end{array}$} & Yes & 323 & 78.02 \\
\hline & & No & 91 & 21.98 \\
\hline \multirow{6}{*}{$\begin{array}{l}\text { Thermo- } \\
\text { regulation }\end{array}$} & \multirow{2}{*}{$\begin{array}{l}\text { Skin to skin } \\
\text { contact prevents } \\
\text { heat loss in your } \\
\text { baby }\end{array}$} & Yes & 121 & 29.23 \\
\hline & & No & 293 & 70.77 \\
\hline & \multirow{2}{*}{$\begin{array}{l}\text { Warm clothing } \\
\text { prevents heat loss } \\
\text { in your baby }\end{array}$} & Yes & 333 & 80.43 \\
\hline & & No & 81 & 19.57 \\
\hline & \multirow{2}{*}{$\begin{array}{l}\text { The first bath } \\
\text { should be given } \\
\text { after } 24 \text { hrs }\end{array}$} & Yes & 397 & 95.89 \\
\hline & & No & 17 & 4.11 \\
\hline
\end{tabular}

Table 4 reveals that 381 (92.03\%) mothers reported that immediate breast feeding soon after delivery of newborns is necessary, $91 \quad(21.98 \%)$ mothers reported that they squeezed out the colostrum before breastfeeding the newborn and regarding exclusive breastfeeding for six months, only 91 $(21.98 \%)$ reported feeding their newborns food or liquid other than breast milk in the first two days. Similarly, 292 (70.58\%) and 115 (27.8\%) mothers replied that they feed their newborn eight to 12 times and on demand respectively. Almost all (98.1\%) newborns were breast-fed and 397 (95.9\%) newborns were initiated breastfeeding within an hour after delivery. All mothers believed that babies should be breast fed at both day and night. Two hundred ninety nine $(72.22 \%)$ mothers knew that vaccines were given to prevent diseases among newborn children whereas the rest $115(27.78 \%)$ did not have such knowledge. Only 217 (52.42 \%) mothers correctly stated that the stump should be uncovered whereas the rest 197 (47.58\%) mothers had preoccupied wrong notion about cord care. All mothers correctly stated that a previously used razor blade should not be used to cut the cord $100 \%$. The umbilical cord was cut with a new or
Table 5. Attitude regarding newborn care among the respondents $(\mathrm{N}=414)$

\begin{tabular}{|c|c|c|c|}
\hline Variable & & Frequency & $\%$ \\
\hline \multirow{2}{*}{$\begin{array}{l}\text { Breastfeeding should } \\
\text { be done at both day and } \\
\text { night }\end{array}$} & Agree & 277 & 66.91 \\
\hline & Not agree & 137 & 33.09 \\
\hline \multirow{2}{*}{$\begin{array}{l}\text { Mixed feeding should } \\
\text { not be practiced }\end{array}$} & Agree & 323 & 78.02 \\
\hline & Not agree & 91 & 21.98 \\
\hline \multirow{2}{*}{$\begin{array}{l}\text { Babies shouldn't be } \\
\text { bathed in cold water }\end{array}$} & Agree & 406 & 98.07 \\
\hline & Not agree & 8 & 1.93 \\
\hline \multirow{2}{*}{$\begin{array}{l}\text { Mother-baby skin to } \\
\text { skin contact prevent } \\
\text { cold }\end{array}$} & Agree & 121 & 29.23 \\
\hline & Not agree & 293 & 70.77 \\
\hline \multirow{2}{*}{$\begin{array}{l}\text { A previously used razor } \\
\text { blade should not be } \\
\text { used to cut the cord }\end{array}$} & Agree & 414 & 100.00 \\
\hline & Not agree & 0 & 0.00 \\
\hline \multirow{2}{*}{$\begin{array}{l}\text { Vaccines are harmful to } \\
\text { your baby }\end{array}$} & Agree & 115 & 27.78 \\
\hline & Not agree & 299 & 72.22 \\
\hline \multirow{2}{*}{$\begin{array}{l}\text { Substances (aside from } \\
\text { those prescribed) can } \\
\text { be applied to infected } \\
\text { eye }\end{array}$} & Agree & 17 & 4.11 \\
\hline & Not agree & 397 & 95.89 \\
\hline
\end{tabular}

boiled blade in $312(75.36 \%)$ deliveries, and 102 (24.64\%) mothers didn't know what was used. Almost all (97.6\%) replied that nothing was applied on the umbilical stump, but $10(2.4 \%)$ had used butter and vaseline. In regards to cloth use, 227 (54.8\%) mothers had used new cloth and 157 $(37.9 \%)$ mothers used old washed cloth. Similarly, $333(80.43 \%)$ mothers believed that warm cloth prevents heat loss from neonate, while $29.23 \%$ mentioned that mother-baby skin to skin contact prevents cold from neonate. In regards to eye care, 397 (95.89\%) mothers reported that redness of eye is indicator of eye infection whereas the rest 17 (4.11\%) did not know about the red eye. Table 5 shows that $33.6 \%$ mothers felt that baby shouldn't be bathed in cold water. Majority of the respondents $404(49.3 \%)$ said they bathed their newborn after one day of birth and 150 (36.2\%) of them said that they bathed the newborn baby immediately. Regarding safety of vaccines, $2.9 \%$ believed that vaccines would harm their children.

The overall knowledge level of the study participants shows that $74 \%$ of the respondents had good knowledge. The overall attitude score of the study participants shows that $77.14 \%$ of the respondents had positive attitude. The overall 
Table 6. Practice regarding newborn care among respondents $(\mathrm{N}=414)$

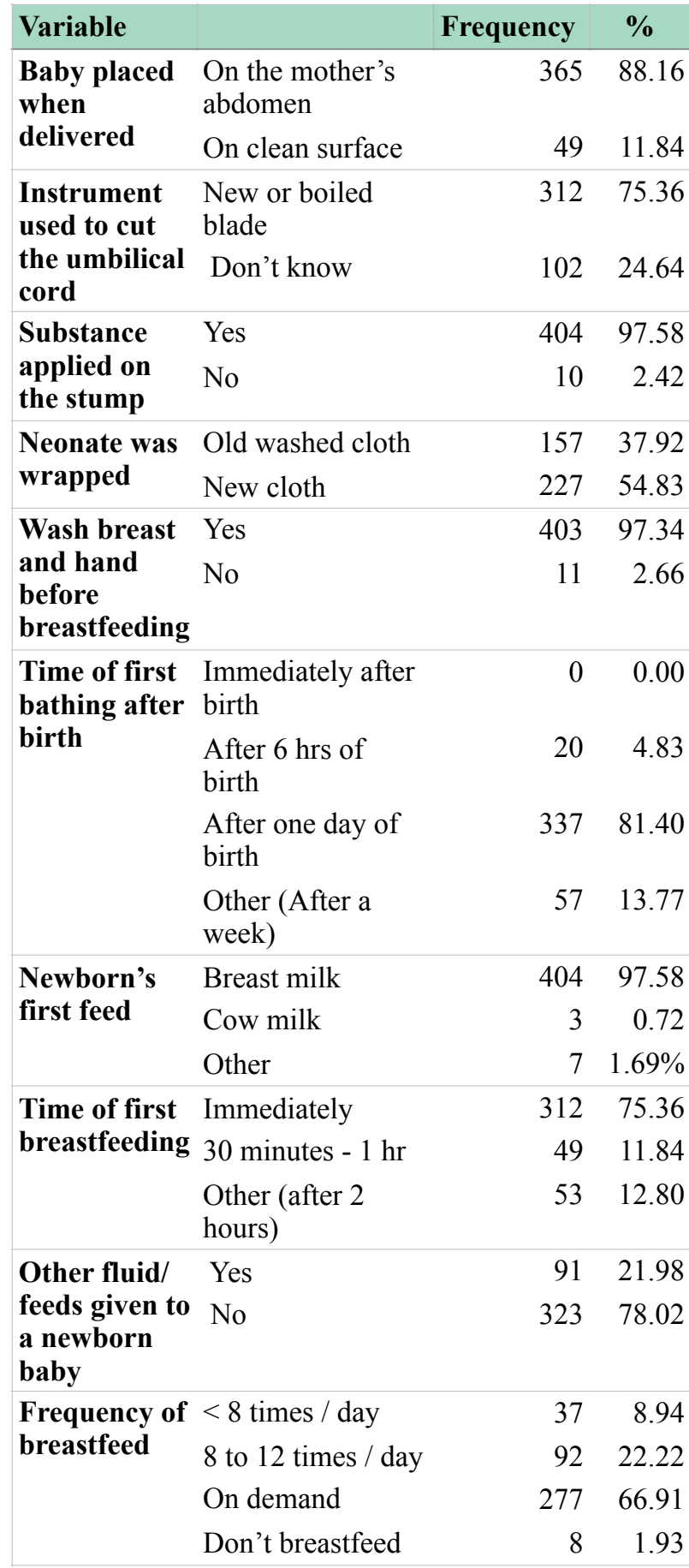

practice score of the study participants shows that majority $65.45 \%$ of the respondents had good practice.

\section{DISCUSSION}

Combating neonatal morbidity and mortality requires equipping mothers with correct knowledge and attitude on newborn care and ensuring

\section{A. Overall knowledge \\ level \\ Good knwoledge \\ Poor knowledge \\ $26 \%$

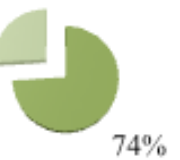

B. Overall attitude level

Good attitude

Not good attitude

$23 \%$

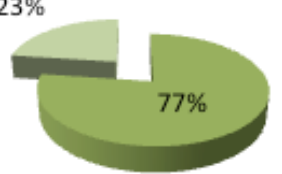

C. Overall Practice level

Good practice

not good practice

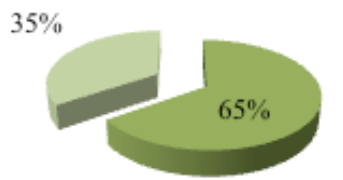

Figure 1 A,B,C. Mothers' overall knowledge, Attitude and Practice level of newborn care in Jugal Hospital,

Harari regional state, Ethiopia, 2019

appropriate practices. The awareness and knowledge among mothers regarding newborn care need to be enhanced in order to achieve better targets in infant and under-five mortality and morbidity. ${ }^{7}$

In this study out of the total respondents interviewed, $74 \%$ of the respondents had good knowledge of newborn care and $77 \%$ of the respondents had positive attitude. This figure is higher than a study done at Madurai, Tamil Nadu, India where $61 \%$ of respondents had favourable attitude $^{8}$, whereas it is lower than the finding of a community-based study conducted in Ethiopia 
$80.4 \% .^{5}$. This discrepancy may be due to the fact that there is socio-cultural difference. We had found that $65 \%$ of the study participants had good practice which is different from other studies done at other parts of Ethiopia. ${ }^{5,9,10}$ Similarly, we found that the overall good ENBC practice was $81.1 \%$ which is different from other studies from Ethipia. ${ }^{5,10}$ Regarding umbilical cord care, $52.42 \%$ of them correctly stated that the stump should be uncovered, kept clean $\&$ dry and $100 \%$ of mothers knew that new blade is used to cut the cord after delivery. This figure is in contrast to similar study done in northern Cameroon and Rohtak, Haryana, India, which had showed the use of sterile material for cutting umbilical cord by $88.5 \%$ and $88.6 \%$ mothers. ${ }^{11,12}$

About breastfeeding, $66.91 \%$ of the study subjects knew that breastfeeding should be on demand, $78.02 \%$ knew about exclusive breastfeeding for 6 months and $75.36 \%$ knew optimal time of breastfeeding initiation is immediately after birth. This finding is much lesser than presented in a study done in Nepal, where all respondents had these knowledge. However, in Southern Tanzania, $83 \%{ }^{14}$ had this knowledge and in Garoua city, Northern Cameroon, only $44.3 \%$ were aware of it. ${ }^{11,14}$ Regarding bathing, $95.3 \%$ bathed their baby after 24 hours of age in our study, which is much higher than previous studies conducted in different parts of Ethiopia in the past. ${ }^{4,10}$ These differences could be explained by various socio-cultural factors, geographic conditions, demographic backgrounds as well as methodological difference of the studies.

Although this study has tried to assess the important aspect of newborn care in Ethiopia, our study has many limitations. It is a single centric, relatively small, cross sectional, questionnaire based study which is liable to recall bias. As the data is collected at a single point in time, we could not establish temporal relationship. Despite these limitations, information gained from this study can be used as a baseline to provide input for developing feasible and sustainable behavioural change and educational interventions. We are hopeful that our study would help increase the awareness among mothers regarding essential newborn care so that the neonatal morbidity and mortality is reduced in the future.

\section{CONCLUSIONS}

This study indicated that nearly half respondents had good knowledge, positive attitude and good practice of newborn care. However, some respondents had below average score of knowledge, attitude and practices of newborn care.

\section{REFERENCES}

1. You D, Hug L, Ejdemyr S, Idele P, Hogan D, Mathers C, et al. Global, regional, and national levels and trends in under-5 mortality between 1990 and 2015, with scenario-based projections to 2030: a systematic analysis by the UN Inter-agency Group for Child Mortality Estimation. The Lancet. 2015 Dec 5;386(10010):2275-86. DOI: 10.1016/ S0140-6736(15)00120-8

2. Group CC. Countdown to 2015 for maternal, newborn, and child survival: the 2008 report on tracking coverage of interventions. The Lancet. 2008 Apr 12;371(9620):1247-58.

3. Macro OR. Central Statistical Agency Addis Ababa, Ethiopia. Ethiopian demographic and health survey 2016

4. Callaghan-Koru JA, Seifu A, Tholandi M, de Graft-Johnson J, Daniel E, Rawlins B, et al. Newborn care practices at home and in health facilities in 4 regions of Ethiopia. BMC Paediatrics. 2013 Dec;13(1):1-1. DOI: $10.1186 / 1471-2431-13-198$

5. Misgna HG, Gebru HB, Birhanu MM. Knowledge, practice and associated factors of essential newborn care at home among mothers in Gulomekada District, Eastern Tigray, Ethiopia, 2014. BMC Pregnancy and Childbirth. 2016 Dec;16(1):1-8.

6. Kabwijamu L, Waiswa P, Kawooya V, Nalwadda CK, Okuga M, Nabiwemba EL. Newborn care practices among adolescent mothers in Hoima District, Western Uganda. PloS one. 2016 Nov 17;11(11):e0166405. DOI: 10.1371/ journal.pone.0166405 
7. Amolo L, Irimu G, Njai D. Knowledge of postnatal mothers on essential newborn care practices at the Kenyatta National Hospital: a cross sectional study. Pan Afr Med J. 2017;28(1):159. DOI: 10.11604/pamj.2017.28.97.13785

8. Darling B, Ranjita S, Wankhede BB. Knowledge, attitude, and practice of postnatal mothers regarding newborn care in selected maternity centers in Madurai. Int J Allied Med Sci Clin Res. 2014;2(2):119-24.

9. Tegene T, Andargie G, Nega A, Yimam K. Clinics in Mother and Child Health Newborn Care Practice and Associated Factors among Mothers who gave Birth within One Year in Mandura District, Northwest Ethiopia. 2015;12(1):1-7. DOI: $10.4172 / 2090-7214.1000172$

10. Kokebie T, Aychiluhm M, Degu G. Community based essential newborn care practices and associated factors among women in the rural community of Awabel district. Int J Adv Sci Res. 2015;1(01):17-27. DOI: 10.7439/ ijasr.v1i1.1637

11. Monebenimp F, Mongo ME, Chelo D, Foumane P, Kamta C, Kuaban C. Mother's knowledge and practice on essential newborn care at health facilities in Garoua City, Cameroon. Health sci. dis. 2013 Aug 7;14(2).

12. Sinha LN, Kaur P, Gupta R, Dalpath S, Goyal V, Murhekar M. Newborn care practices and home-based postnatal newborn care programme-Mewat, Haryana, India, 2013. Western Pacific surveillance and response journal: WPSAR. 2014 Jul;5(3):22. DOI: 10.5365/WPSAR.2014.5.1.006

13. Shrestha T, Bhattarai SG, Silwal K. Knowledge and practice of postnatal mother in newborn care. Journal of Nepal medical association. 2013;52(190). PMID: 24362663

14. Penfold S, Hill Z, Mrisho M, Manzi F, Tanner M, Mshinda H, et al. A large cross-sectional community-based study of newborn care practices in southern Tanzania. PloS one. 2010 Dec 21;5(12):e15593. DOI: 10.1371/journal.pone. 0015593 